\title{
The impact of the characteristics and behaviors of the board of directors on agency costs in Iran
}

\section{El impacto de las características y comportamientos de la junta directiva sobre costos de agencia en Irán}

\author{
Mahdi Salehi*, Zakiyeh Sadatifar, Mohammad Sadegh Adibian \\ Ferdowsi University of Mashhad, Irán
}

Received January 8, 2019; accepted November 11, 2019

Available online October 6, 2020

\begin{abstract}
The present study aims to identify the contributing factors to agency costs in Iran applying panel data technique for financial data of 112 listed companies on the Tehran Stock Exchange from 2011 through 2017. Three models of measurement namely (1) inverse asset turnover ratio; (2) operational cost to sales ratio; and (3) the index obtained from the factor analysis of inverse variables of asset ratio and operational cost to sales ratio are used. The obtained results indicate that the greater number of board directors' meeting may improve the level of agency costs (based on two cost models), and it also may increase the level of agency costs (based on one model). Second, the results of the paper show that the higher educational level of boards' members may also decrease the agency cost. Moreover, we evidence that the presence of women in the board of directors, and the ownership of firms' share by the members of the board of directors may increase the level of agency cost for firms. Since only one (out of three) model suggests these associations, our findings are less severe in these regards. Further analyses document that appointing one of the board director's members as chief executive officer (CEO duality) plies no effective role in mitigating the agency cost. The similar findings, based on our three cost models, suggest a robust conclusion in this context.
\end{abstract}

JEL code: G10, M42, M41

Keywords: Agency costs; Factor analysis; Board expertise; The presence of women on the board; CEO duality; compensation

* Corresponding author.

E-mail address: mehdi.salehi@um.ac.ir (M. Salehi).

Peer Review under the responsibility of Universidad Nacional Autónoma de México. 


\section{Resumen}

El presente estudio tiene como objetivo identificar los factores que contribuyen a los costos de agencia en Irán aplicando la técnica de datos de panel para datos financieros de 112 empresas que cotizan en la Bolsa de Valores de Teherán desde 2011 hasta 2017. Tres modelos de medición, a saber (1) índice de rotación de activos inversa; (2) relación entre el costo operativo y las ventas; y (3) se utiliza el índice obtenido del análisis factorial de variables inversas de razón de activos y razón de costo operacional a ventas. Los resultados obtenidos indican que el mayor número de juntas de directores puede mejorar el nivel de costos de agencia (basado en dos modelos de costos), y también puede aumentar el nivel de costos de agencia (basado en un modelo). En segundo lugar, los resultados del documento muestran que el mayor nivel educativo de los miembros de las juntas también puede reducir el costo de la agencia. Además, evidenciamos que la presencia de mujeres en la junta directiva y la propiedad de la participación de las empresas por parte de los miembros de la junta directiva pueden aumentar el nivel de costo de agencia para las empresas. Dado que solo uno (de cada tres) modelo sugiere estas asociaciones, nuestros hallazgos son menos severos en estos aspectos. Los análisis adicionales documentan que nombrar a uno de los miembros del director de la junta como director ejecutivo (dualidad del CEO) no desempeña un papel efectivo en la mitigación del costo de la agencia. Los hallazgos similares, basados en nuestros tres modelos de costos, sugieren una conclusión sólida en este contexto.

Código JEL: G10, M42, M41

Palabras clave: Costos de agencia; Análisis factorial; Experiencia de la junta; La presencia de mujeres en el tablero; Dualidad de CEO; Compensación

\section{Introduction}

Regarding the incremental rate of companies' development, capital wealth and number of investors, it is suggested that directing companies by shareholders seems to be impossible. Thus, investors decide to appoint people possessing some required specializations under the title of manager, which has led to the issue of separation between ownership and management. In other words, Investors appoint some agents in firms, who are responsible for decision-making and directing daily affairs (Jensen, 1998). There are some different definitions proposed for agency theory. For instance, the equity owners will attribute the management responsibility to the managers by assigning a contract (Jensen and Mackling, 1976). Some managers prefer not to disclose some information on companies to preserve the internal budget and increase the investment opportunity. Such action may provide a kind of information asymmetry between shareholders and managers (Kalay, 2014). Hence, the separation of ownership and 
management may provide some problems for companies, including conflict of interest and information asymmetry between manager and shareholder (Teixeira, 2012; Jiraporn et al. 2012). These problems are due to showing opportunistic behavior by managers, including their concentration on self-interests, excessive use of capital, and inappropriate investment decisions (Buchwald, 2016). The opportunistic behaviors of management depend on the amount of management power and its credit in companies (Stagliano and Racca and Recca, 2014). This caused the shareholders to find their wealth and interests at risk and bear some costs to maintain their assets, which is called the agency cost (Chernenko, Foley and Qreen Wood, 2012). Based on the agency theory, the agent is expected to make wise decisions in line with maximizing the interests of shareholders. However, it is worth mentioning that the amount of agency cost, which shareholders are likely to bear depends on the amount of investment and the size of the company (Aslan and Kumer, 2014). Different types of agency costs introduced by Jensen and Mackling (1976). (1) Monitoring (control) costs: such costs which are incurred by the owners or the shareholders might lead to monitoring manager's behavior, including the compensation cost of managers and employing independent auditors; (2) Compulsory costs: The costs incurred or consumed resources by a manager to increase the trust of shareholders instead of shareholders' wealth maximization; (3) Residual loss: in addition to monitoring cost, there are some residual expenses pertain to decision making process in line with maximizing the interests of managers instead of shareholders (Cadot, 2013).

The members of a family manage some companies; namely, the ownership and management of the company are held by the members of a family (Wangfang and Lihang, 2015). Through the family ownership, since a considerable portion of ownership takes part in the management, it is suggested that there are fewer agency problems. In such companies, ownership has more control over management performance (Villalonga and Amit, 2006).

To lower the agency costs, shareholders require a mechanism for controlling and decreasing the problem, and one of the mechanisms in corporate governance. By improving the performance of a company using appropriate corporate governance, the firm's stock value increase, and an opportunity may be provided for capital absorption (Yeo, 2012). Hence, by improving the governance, not only the desired capital is more likely to be provided from the local markets by the investors, but also the overseas investors are expected to be attracted by these companies. Having improved performance and disclosed sufficient the information between shareholders and owners, good corporate governance might be able to reduce the conflict of interest, decrease information asymmetry between shareholder and manager, satisfy investor, and finally provide a lower agency cost (Hang, Li, and Minor, 2015).

According to these academic gaps, we are motivated to apply the current study to answer the question of whether the behavior and characteristics of the board contribute to the agency 
costs or not. In other words, whether the board characteristics lead to the decline of the agency costs, and it might result in improving firms' performance.

The remainder of the study is as follow; Section 2 describes the related line of literature and develops paper's hypotheses. Section 3 discusses the data and details the empirical methods. Section 4 presents the results; section 5 discusses the findings and concludes the paper.

\section{Theoretical issues and hypotheses development}

Recently, corporate governance has attracted many scholars of financial fields, especially after the recent financial scandals in large stock companies, involving Enron and WorldCom in the U.S. Congress, Marquees in England, and Royal Ahold in the Netherlands (Fidanoski and Mateska and Simenovski, 2014; Merendine, 2013). These scandals point the need for improving the strategic mechanisms of firms and increasing transparency in accounting figures. Several definitions proposed for corporate governance so far. Mazlina and Ayaib (2011) define corporate governance as a set of procedures and structures to direct and manage the business activities of a firm to increase the shareholders' wealth. Karati (2014) states that corporate governance is a mechanism defining how managers can be prevented from seizing the shareholders' wealth. Hence, corporate governance is a set of interrelated regulations enabling firm, shareholders and management to control their behaviors and make wise decisions about the ownership structure, which in turn may stable their relationship by improving the structure of the board, financial information disclosure, etc. (MohdSaad, 2010). Thus, the mechanisms of the corporate governance system are known as a controlling system of firms, which determines the domain of responsibilities of authorities such as the board of directors, managers, shareholders, and other related beneficiaries. Generally, the mechanisms of the corporate governance system are classified into internal and external groups. The internal mechanisms of the corporate governance system refer to the natural process of monitoring of senior managers on subordinate managers, and the external ones are concerned about managerial career, monitoring the capital market through financial analysts, institutional ownership, significant shareholders, and the controlling market of the company (Hi and Sommer, 2010). Therefore, the mechanisms of corporate governance have various aspects, which could reduce the agency conflict and may include a different aspect that supersedes or complement each other (Dey, 2008). 


\section{The board activity (effort)}

The attempt of developing countries to achieve sustainable development or for becoming a developed country is growing increasingly (Claretha, 2018). Most developing countries suffer from the high cost of production. The production developments lead to countries developments, and the training and enhancing human resources are the first steps for achieving such an objective. It seems that training the board, as a supporting institution holding a caring role, is a matter of thought. Board activity is one of the major topics in the internal structure of the board (Arosa, Iturrade, and Maseda, 2013). According to the findings of previous investigations the following qualifications are proposed for a successful board of directors: (1) Holding the board sessions regularly; 2) Holding a balanced power between the board's members; (3) Establishing a high level of reliability among the members; and (4) Holding the responsibility of financial statements by the board. The board members should take the opinion of the other members into account patiently, and assess the firm performance in every session. It is noted that the number of productive sessions maximizing the wealth of shareholders must be increased, whereas the number of sessions that less likely to be efficient is supposed to be decreased (Ilaboya and Obaretin, 2015). Johl et al. (2013) find that duality has a negative effect on firms' performance. They also evidence that the presence of independent or unbounded managers does not improve the firm performance by increasing the effort of managers to make better decisions in strategic planning. Ilaboya and Obaretin (2015) show that there is a positive and significant relationship between audit committee independence and firm performance in Nigeria, and they also report a negative relationship between board effort and performance. The recent studies also find a positive impact of the number of boards' meeting on firms' performance in India (Abdul Gafoor et al., 2018) as well as in Nigeria (Eluyela et al., 2018). Gray, S. and Nowland, J. (2018) examine whether increased director workloads are benefiting firms or are causing directors to become too busy, resulting in lower director attendance and weaker firm performance. They find that attendance rates for both outside and inside directors decrease as they are required to attend more meetings. The benefits firms obtain from holding additional meetings are significantly eroded by lower director attendance. Agung et al. (2019) reveal that the board of director meeting has a positive impact on market value-based performance and the board of director meeting attendance has a positive impact on accounting-based performance. However, Petchsakulwong \& Jansakul (2018) conduct research on insurance companies in Thailand; they indicate that more meeting times of the board increase the cost of management, leading a decrease in the profitability ratio.

$\mathrm{H}_{1}$ : Greater number board's sessions play a rectifying role in agency problems. 


\section{Managerial ownership}

The agency theory also declares that managers with angry and harsh temperaments may misuse the firm assets and cause information asymmetry. The available literature shows that the approach of an entrepreneur manager is different from an owner-manager (Jensen and Meckling, 1976; Jusoh and Che-Ahmad, 2014).

The presence of agency problem, and the tendency of managers for earnings management, misusing, and consequently unfair presentation of financial reports to shareholders (incorrect disclosure), not only at the micro-level result in the loss of shareholders but also at the macro-level cause severe damage to the trust of shareholders, in which they are likely to be separated from the stock market (Keasey et al., 2005). In companies, owners usually establish some monitoring policies for control the agent's activities to obtain that whether they are by the interests of owners or not. However, it is a commonplace that managers consider their benefit as well, leading to the conflict of interests between the objectives of shareholders and managers and increasing the agency costs. Thus, corporate governance is necessary for balancing the interests of shareholders and management at the aim of lowering agency costs. Companies in developing countries try to decrease the agency costs to enter the international markets, and also to attract the capital of those who are willing to invest in their company. The decrease of the agency costs ensures investors that their interests are protected, which in turn may attract them to have a greater investment.

Previous studies reveal that managerial ownership is one of the factors that mitigate the conflict of interests between shareholder and managers. Managerial ownership is indicative of the number of shares held by the firms' managers (Wangfang and Lihang, 2015). Managerial ownership is proposed as a challenging issue in the topic of corporate governance, which mainly implies to the number of firm's shares holding by managers of the firm, because this group, on the one hand, has access to the internal information and hidden news of the firms, and on the other hand, are expected to make diligent decisions. According to the agency theory, managers are motivated to enhance their position, reputation and credit, facilities, at the cost of the firm (Jensen and Mackling, 1976). The agency cost is the cost incur by the management for excessive use from peripheral advantages, leisure, evasion, and use of job facilities of managers. Holding a certain amount of shares by the managers of firms could align the interests of shareholders and managers. Even if managers have more ownership, they may make more effort to improve the performance of the firm under their control. Therefore such a process may decrease the agency costs (Henry, 2010). Ang et al. (2000) show that there is a negative relationship between management ownership and agency costs, and the increase of such costs is directly related to the growth of several non-manager shareholders. 
Cui and Mak (2002) show that the monitoring costs of debt security holders will be increased by the reduction of ownership percentage of a manager. Singh, Davidson, and Henry (2003) investigate the relationship between ownership structure and the agency cost and found that the increase of management ownership could lower the agency cost. Fleming et al. (2005) conclude that the agency costs, derived from the conflict of interest between owners, managers, and external shareholders, would be decreased by the increase of managers' ownership.

However, the conflict of interests between shareholders and debt security holders is more complicated. High debt ratio will lead to the increase of monitoring activity of debt security holders and consequently decreases the agency cost. The more the debt ratio increases beyond a certain threshold in the capital structure, the more inverse impact it has on the agency cost. Muler and Spetes (2006) reveal that the performance of companies with managerial ownership of more than $40 \%$ is improving. Florackis (2008) conducted a study on the impact of corporate governance mechanisms on agency costs. He discovered that managerial ownership, management compensation, and ownership concentration contribute significantly to the discount of the agency costs. Li and Chanki (2008) find that when the management ownership ratio is less than $36 \%$ or more than $59 \%$, by one percent of the increase in this ratio, the management efficiency for appropriate use of assets will be declined and this will cause in the increase of agency costs. However, suppose the management ownership is between $51 \%$ and $59 \%$, by one percent of the increase. In that case, the management efficiency for appropriate use of assets will be increased, and the agency costs will be decreased. Ahmad and Mustafa (2011) indicate that there is an inverse relationship between the percentage of management ownership and agency costs. Fatma (2011) discovered that managerial ownership could be used for reducing agency costs. Sajid et al. (2012) find that the managerial ownership could lower the agency costs, in contrast, Salehi et al. (2018) show that there is not any considerable association between the board ownership and audit fees in Iran country. Rashid (2016) declares that there is a significant relationship between the ownership of a manager and the agency cost. Balasingham et al. (2017) analyzes the impact of board independence and managerial ownership on the agency cost and discovers a significant relationship between board independence, managerial ownership, and agency costs. Within a study, entitled "analyzing the agency theory: a review on the problems and outlook of the agency theory", Panda and Leepsa (2017) find that the separation of ownership from management may result in the conflict of interest, agency costs, imposing different commercial risks, information asymmetry, and ethical risks. Controlling the manager's power, manager's ownership, the independence of audit committee members, and establishing various committees could help deal with problems and the agency costs. Mark et al. (2019) find that in state-owned enterprises (SOEs), taxes are a dividend to the controlling shareholder, the state, but a cost to other shareholders. They link 
such results to managerial incentives, finding that higher SOE tax rates are associated with higher promotion frequencies of SOE managers. Their results suggest managerial incentives and tax reporting are conditional on the ownership structure of the firm.

Considering the above discussion, we conduct the second hypothesis as follow:

$\mathrm{H}_{2}$ : Owning a firm's share by the board's members plays a rectifying role in agency problems.

\section{The board's financial expertise}

A consistent economic development leads to the growth of social welfare, which is one of the essential features of capita income (Wang and Dalko, 2018). Developing countries generally suffer from a lack of financial knowledge and technical information to fulfil their production objectives. One of the significant economic problems of developing countries is the high fixed price of goods and services in comparison to the low quality of their products. Hence, managers are expected to make diligent and timely decisions to improve a firm's products or services by decreasing the fixed price of goods and services and improving the favorable quality. The board of a company, as the governing body is responsible for controlling the work of executive managers by monitoring the manager's decisions, which in turn may improve firm's performance (Vo and Phan, 2013).

The reported information of World Bank in 2017 suggests that the developed countries generate almost $83 \%$ of the world income. This is while the population of these countries accounts for $23 \%$ of the world population. However, less than $20 \%$ of the world income is derived from developing countries, with $77 \%$ of the world population. The developing countries similar to Iran have embarked upon a valiant attempt for economic development, raised their shares of the world production, and allocated a higher portion of the percentage of per capita income to them. Therefore, companies in such countries, in addition to making efforts to increase their products based on the needs and customers' demand, attempt seriously to improve the quality of a product as well as lower the price of the products through reducing companies' costs including agency costs. Moreover, it is recommended that the knowledge and expertise in related fields of studies are likely to be incorporated with better supervision on the manager's work in issues related to finance, marketing, fixed price, etc. (Vo and Phan, 2013).

Prior studies suggest that a knowledgeable board and experience in a related industry is more successful (Ilaboya and Obaretin, 2015), and increase education plays a vital role in gaining professional expertise, which in turn may enhance directors' cognitive skills. Therefore, it is expected that more educated directors may realize, analyze business matters more easily and propose more sufficient solutions (Johnson et al. 2013; Jiang et al., 2016). Also, 
having knowledge and expertise in the desired profession could cause better supervision on manager performance in issues related to financial, marketing, accounting, and legal affairs (Vo and Phan, 2013). Lack of supervision knowledge in a related industry is due to the inaccessibility of expert staff, and this could enhance the agency cots. In this regard, Vo and Phan (2013) conduct a study on corporate governance and firm performance. They found a positive relationship between the knowledge and experience of board and firm performance. More recent investigations, including Harjoto et al. (2019) examine the relationship between the nationality and educational background diversity of directors serving on corporate boards and the firms' corporate social performance (CSP). They find that board nationality diversity and educational background diversity are positively associated with CSP. Salehi and Farzaneh (2018) examine the effects of the board's human capital on the relationship between the board's characteristics and firm's performance. Their results indicate that firms benefit from board human capital in terms of outside directors' proficiency, validity, experience, speciality and knowledge to monitor and counsel managers. Salehi et al. (2018) show that the audit committee's expertise, proxied by its' members' educational background, play a significant role in the improvement of a company's profitability.

However, Van Ness et al. (2010) discover that there is a negative relationship between board expertise and firm performance. Schmidt (2019) suggest that educational levels or board gender quotas do not affect the positive relationship between board gender diversity and firm performance. Elmagrhi et al. (2019) do not show any evidence that suggests that the level of education of female directors has any impact on environmental performance, neither the overall environmental performance measure nor its individual components. Consequently, we expect that having financial knowledge with the board's member leads to a firm's performance improvement. Berezinets et al. (2019) suggest that intellectual capital (IC) is generated not only by company staff but also by governing bodies, particularly the board of directors (BDs), whose members are not always under contract with the company in the traditional sense. Members of the board use their knowledge, experience, and networking opportunities to build IC for effective monitoring, advising, and providing the company with resources. In this sense, the BDs serves as a source of IC for a company, being the main internal corporate governance mechanism that leads to value creation in a company, taking into consideration the interests of all stakeholders. According to the above discussion, the following hypothesis is developed:

$\mathrm{H}_{3}$ : Having financial expertise with the board's members plays a rectifying role in agency problems. 


\section{Presence of women in the board}

Prior studies show that companies with more women on their board have lower agency costs (Antoni et al., 2011). Several advantages are proposed for the gender diversity on the board, including the growth of the board's independence and the quality of decisions. It is worth mentioning that the female members have fewer problems participating in the board sessions may increase the effectiveness of such sessions (Kilic, 2015). The available articles on this topic show a gradual but consistent increase in women presents on the board, globally. For example, within the Norwegian Constitution, a minimum of 40 women must be included in the boards of directors. Before the Norwegian Law in 2003, only $7 \%$ of the board members in this country were women. Similar laws are adopted in Netherland and Sweden. In France, a law introduced in early 2011 legalizing the presence of women. A specific share is also enacted in the stock companies of Belgium, Canada, and Italy by following different procedures. Since women constitute more than $50 \%$ of the world population, their role in economic development and the growth of the gross national product, especially in developing countries, should not be ignored.

The increase in per-person income of developing countries relies on the growth of production amount and the decrease in costs. The presence of women in the company boards of developing countries could lower the agency costs (Jukus et al., 2011). Through their good relations and acceptable behaviors with women customers and other staffs, women may improve firm performance and increase income, which is counted as one of the main factors for developing countries. Hence, women as economic partners contribute significantly to the development trend and are considered as primary factors of development. Within the past two decades, the issue of the presence of female members on the boards of directors in large corporations comes into vogue (Wellalage and Locke, 2013). A heterogeneous board is likely to cause the formation of different views on different issues, leading to the availability of more information, and finally, provide better solutions. Besides, gender diversity may establish a communication channel through good behaviors and relations of women with female customers and others (Kilic, 2015). Jurkus et al. (2011) analyzed the relationship between the presence of women in senior management and agency costs. Their obtained results indicate that the increase of female percentage at senior management level could mitigate the agency costs. Geranina and Kaikova (2016) show that the number of female members has an insignificant impact on America, a negative impact in Norway on agency costs, and an insignificant impact in Russia. They also show that American and Russian companies have fewer agency costs in the sample. Galbreath (2016) noticed that the presence of women on the board would affect the so-called variable. Abdullah and Ismail (2016) show that, while women on boards are not associated with income-decreasing accruals, the presence of women 
on audit committees leads to income-reducing earnings management. It is also revealed that a higher percentage of women in boardrooms and groups of outside and independent directors imply better CSR disclosure. These results hold for corporations with a critical mass of three women on the board and among outside directors (Cabeza-García et al., 2018; Gulzar et al., 2019). According to presented literature, having women members on the board is likely to reduce agency cost. Therefore the following hypothesis is conducted:

$\mathrm{H}_{4}$ : Having women members on the board plays a rectifying role in agency problems.

\section{CEO duality}

In developing countries similar to Iran, corporate governance has several advantages. Corporate governance in such countries might cause a high and stable rate of growth in the national economy. CEO duality is one of the variables of corporate governance limiting management decision-making. For the establishment of such governance, the CEOs must not necessarily be engaged in the board of director's membership.

Creating a balance of power among board members may disable individuals to have significant control over the process of decision-making, unconditionally. For better governance in a company and reducing the effective influence of every individual in strategic decisions, it is better to maintain a balance of power in firms, in which the separation of the role of board's director and the CEO should be taken into account (Wellalage and Locke, 2011). Some scholars believe that exercising careful supervision could protect the interests of shareholders (Arosa et al., 2013). The more the influence of the CEO on the board, the less inappropriate investment decisions or perform doubtful earnings management (Andro et al., 2012). Separation of duties of the board director and CEO is one of the factors guarantees the robustness of the board and consequently, the survival and improvement of the organizational performance. Sajid et al. (2012) recognized that separating the position of board directors' member and CEO, and also enhancing the compensation may alleviate the agency cost. Arosa et al. (2013) concluded that duality has a negative effect on firm performance.

Bhatt and Charya (2017) discovered that duality has an insignificant effect on firm performance. Elhaj et al. (2017) evaluate the impact of the board characteristics on the Sukuk rating in Malaysia. Their results indicate that duality may cause more responsibility for decision-making and improve the performance of the Sukku rating. However, in an interesting study in Iran market, Salehi, Tahervafaei, \&Tarighi (2018) inferred that CEO duality does not affect financial performance, whereas audit committee financial expertise is positively associated with profitability. 
Owusu and Weir (2018) found that there is a significant relationship between the board size, the presence of audit committees, and compensation and the agency costs, whereby the last two variables can cause the decrease of the agency costs. According to these findings, we expect a positive association in this regard. Therefore the following hypothesis is conducted:

$\mathrm{H}_{5}$ : Lack of dual CEOs on the board plays a rectifying role in agency problems.

\section{The board independence}

Board independence in developing countries is not common (Rashid, 2018). The presence of unbounded members in the board composition may cause more supervision on the performance of CEOs. A board is called independent when there is no bounded and high-rank executive manager among the members (Ilaboya and Obaretin, 2015). The board of directors with independent members and the required legal authority is potentially an effective mechanism to lower agency costs.

Salehi, Tarighi, \& Safdari (2018) realize that the independence of board members does not affect audit fees in Iran market; they consider audit fees as a measure for audit effort demand. Rosenstein and Wyatti (1990) notice a direct relationship between the increase of unbounded managers in the board and firm value. Ahmed and Sanda (2008) find that the number of unbounded managers is significantly associated with firm performance. Sajid et al. (2012) show that board independence has a positive relationship with the return on the asset in companies listed in Karachi Stock Exchange. Rashid (2015) suggest that board independence can only lower the agency costs from the perspective of asset ratio. Habib and Bhuiyan (2016) indicate that the unbounded members of the board have a positive impact on the relationship between the audit committee and real earnings management, and this impact is stronger for bounded managers with fraudulent report problems. Balasingham et al. (2017) demonstrate a significant relationship between board independence, managerial ownership, and agency costs. Panda and Leepsa (2017) find that the separation of ownership from management may result in the conflict of interest and agency costs, which in turn impose different commercial and ethical risks as well as information asymmetry. Owusu and Weir (2018) find a negative relationship between the board size, the presence of audit committees, and compensation and the agency costs and the agency costs. According to these findings, we expect a negative association in this regard. Therefore the following hypothesis is conducted:

$\mathrm{H}_{6}$ : Having an independent board's members plays a rectifying role in agency problems. 


\section{The board compensation}

It is considered as an appropriate corporate governance framework to facilitate the objectives of a firm and improve the firm performance through lowering agency costs and improving the firm efficiency (Henry, 2010; Salehi, Tarighi, \& Safdari, 2018). Salehi, Tarighi, \&Safdari (2018) document a positive association between audit fees and delta, but not Vega; this means that a fee premium is linked to CEO Delta incentives. They proved that Iranian companies pay more audit fees when they give managers more compensation as well. Florackis (2008) find that managerial ownership, management compensation, and ownership concentration contribute significantly to the agency costs discount. Sajid et al. (2012) express that the increase in compensation of managers lowers the agency costs. Owusu and Weir (2018) find a significant relationship between the board size, the presence of audit committees, and compensation and the agency costs, such that the last two variables lead to decrease in the agency costs. According to these findings, we expect a negative association in this regard. Therefore the following hypothesis is conducted:

$\mathrm{H}_{7}$ : Greater paid compensation to the board's members plays a rectifying role in agency problems.

\section{Research methodology}

The total required data to test the hypotheses are collected directly from the financial statements on the Tehran Stock Exchange website. After collecting the required data from reliable and available resources, the data are analyzed using the Eviews software.

The statistical population includes all listed companies on the Tehran Stock Exchange. In this study, the screening method is employed for sample selection, such that first all companies from 2011 to 2017 are included since related data of this investigation are only available for this period. From the available companies, those with the following qualification are selected,

- Listed in Tehran Stock Exchange Market before 2011;

- Their financial yearend be on March 20th.

- Should not change their fiscal year; and,

- Should be active during 2011-2017.

- Listed companies in the financial intermediary, holdings, and banks industries are excluded 
from coordinating the data. This is because such companies differ, in terms of nature of activities, the classification of financial statements items and possessing assets, from manufacturing companies. It is noticeable that most service companies are a subgroup of these excluded industries.

Given the above limitations, finally, a total of 112 listed companies on the Tehran Stock Exchange are selected as the sample of the study.

Research models and variables

Based on the theoretical principles and related literature of the study, the following models are used. The empirical models of this study are as follow:

Model 1:

$A C O S T 1_{\text {it }}=\beta_{0}+\beta_{1} B E_{i t}+\beta_{2} M O N_{\text {it }}+\beta_{3} B S P_{\text {it }}+\beta_{4} B W O M_{\text {it }}+\beta_{5} D U A L_{\text {it }}+\beta_{6} I B D O_{\text {it }}+$ $\beta_{7} R E M S T R_{\mathrm{it}}+\beta_{8}$ TENUE $_{i t}+\beta_{9} S I Z E_{i t}+\beta_{10} R O A_{i t}+\beta_{11} D E B T_{i t}+\sum y e a r+\mathrm{e}_{\mathrm{it}}$

Model 2:

$A C O S T 2_{i \mathrm{it}}=\beta_{0}+\beta_{1} B E_{\mathrm{it}}+\beta_{2} M O N_{\mathrm{it}}+\beta_{3} B S P_{\mathrm{it}}+\beta_{4} B W O M_{\mathrm{it}}+\beta_{5} D U A L_{\mathrm{it}}+\beta_{6} I B D O_{\mathrm{it}}+$ $\beta_{7} R E M S T R_{\mathrm{it}}+\beta_{8}$ TENUE $_{i t}+\beta_{9} S I Z E_{i t}+\beta_{10} R O A_{i t}+\beta_{11} D E B T_{i t}+\sum y e a r+\mathrm{e}_{\mathrm{it}}$

Model 3:

ACOST $3_{\text {it }}=\beta_{0}+\beta_{1} \mathrm{BE}_{\mathrm{it}}+\beta_{2} M O N_{\mathrm{it}}+\beta_{3} B S P_{\mathrm{it}}+\beta_{4} B W O M_{\mathrm{it}}+\beta_{5} D U A L_{\mathrm{it}}+\beta_{6} I B D O_{\mathrm{it}}+$ $\beta_{7} R E M S T R_{\mathrm{it}}+\beta_{8}$ TENUE $_{i t}+\beta_{9} S I Z E_{i t}+\beta_{10} R O A_{i t}+\beta_{11} D E B T_{i t}+\sum y e a r+\mathrm{e}_{\mathrm{it}}$

\section{Dependent variable:}

ACOST1: is the asset utilization ratio, which is measured by annual sales divided by total assets. This ratio is a measure of how effectively the firm's management deploys its assets. In this regard, agency costs are inversely related to the sales-to-asset ratio. A firm whose salesto-asset ratio is lower than the base case firm experiences positive agency cost. These costs arise because the manager i) makes poor investment decisions, ii) exerts insufficient effort, resulting in lower revenues; iii) consumes executive perquisites, so that the firm purchases unproductive assets, such as excessively fancy office space, office furnishing, automobiles, and resort properties (Ang et al., 2000). 
ACOST2: is the operating cost to sales ratio. Operational costs include marketing, sales advertising, and rent costs and in fact, reflect the managerial authorities in consuming the firm resources. This index is used as the direct criterion of the agency costs, namely, the more the index, the higher the agency costs would be. Therefore, the operational cost of the sales ratio is slightly indicative of managerial authorities in spending the resources (Florackis, 2008). The exact measurement of the agency costs is absolutely one of the most complicated issues. Two variables of inverse assets turnover ratio and operational costs to sales ratio show the relative amount of the agency costs, but no one could completely show the status of the agency costs and only allocate some ratios to the agency costs from different perspectives. Hence, factor analysis carried out to achieve an index for both variables and SPSS25 Software, KMO test statistic, and the Bartlett test was used to recognize the appropriateness of the data. The value of KMO test statistic is 0.54 , which is smaller than 0.5 , so factor analysis cannot be used. Suppose the statistic is between 0.5 and 0.7. In that case, it means that we can employ the factor analysis and the value of more than 0.7 means that the factor analysis can be used strongly, so we can cautiously say that data are suitable for the factor analysis. Using the Bartlett test, we tested the null hypothesis proposing that the correlational matrix among the variables is related to a community with non-correlated variables and the resultant level of probability is 0.01 , so the null hypothesis is rejected, and data are suitable for the factor analysis.

ACOST3: is achieved from the factor analysis of two variables of inverse assets turnover ratio and operational costs to sales ratio and shows the agency costs. Factor analysis is a statistical method describing variability among observed, correlated variables in terms of a potentially lower number of unobserved variables called factors. Considering such a method, the observed variations in two other variables may reflect the variations in one unobserved (underlying) variables. Factor analysis is applied to determine such joint variations in response to unobserved latent variables, which is expected to observe clearer results.

\section{Independent variables:}

Board effort (BE): is the number of board sessions held during a year. To measure the amount of the board effort and activity, Arosa et al. (2013) have also used the number of board sessions held during a year.

Managerial ownership (MON): to measure the managerial ownership, we use the number of shares that are owned by the board of directors' members as an index, which is employed by Illaboya and Obaretin (2015).

Board expertise (BSP): based on the previous studies, including Illaboya and Obaretin (2015), it is an indicator variable representing; if at least, one of the board members has a $\mathrm{PhD}$ degree, it takes 1 , and 0 otherwise. 
Women' presence in the board (BWOM): is an indicator variable representing; if at least, one woman is working in the board it takes 1 and 0 otherwise.

CEO duality (DUAL): based on the study of Von and Phan (2013), it is an indicator variable representing; if one of the board director's member is also the chief executive officer (CEO) of the company, it takes 1 , and 0 otherwise.

Board independence (IBDO): given the study of Illaboya and Obaretin (2015), it is the number of independent managers, who do not have a financial interest in firms, in the board scaled by total board members.

Board compensation (REMSTR): is the raw amount of compensation of the board of directors, which is disclosed in the financial statements.

\section{Control variables:}

CEO tenure (TENUE): if the manager is responsible for the company for more than three years, it takes 1 , and 0 otherwise;

Firm size (SIZE): natural logarithm of firm assets;

Return on assets (ROA): net profit to total assets ratio;

Financial leverage (DEBT): total debts to total assets; and,

YEAR: dummy variable of year.

\section{Results}

\section{Descriptive statistics:}

The descriptive statistics of the research variables are calculated for the initial analysis of the data and presented in Table 1. It is given in Table 1, the relative closeness of median and mean in most of the variables suggests all variables have an appropriate statistical distribution and their standard deviation is not 0 . Therefore variables can be put into the model. The standard deviation shows the dispersion of data from the mean. Low standard deviation show low dispersion of data and high standard deviation means a high dispersion of data from the mean. The variable of disclosed board compensation with the standard deviation of 3806 has the maximum dispersion, and the variable of CEO duality with the standard deviation of 0.12 has the minimum of dispersion from the mean. By evaluating the coefficient of kurtosis, it is obtained that all variables under study have a positive kurtosis coefficient, longer than the normal distribution. 
Table 1

Descriptive statistics

\begin{tabular}{|c|c|c|c|c|c|c|c|}
\hline Variables & Mean & Median & Maximum & Minimum & $\begin{array}{l}\text { Standard } \\
\text { deviation }\end{array}$ & Skewness & Kurtosis \\
\hline ACOST1 & 1.49 & 1.27 & 7.28 & 0.15 & 0.88 & 1.79 & 8.53 \\
\hline ACOST2 & 0.31 & 0.12 & 38.31 & 0.00 & 2.00 & 15.56 & 262.39 \\
\hline ACOST3 & 1.16 & 0.96 & 22.29 & 0.06 & 1.15 & 10.57 & 170.54 \\
\hline $\mathrm{BE}$ & 16.17 & 14.00 & 48.00 & 5.00 & 5.99 & 2.23 & 10.00 \\
\hline BSP & 0.70 & 1.00 & 1.00 & 0.00 & 0.49 & 0.10 & 8.99 \\
\hline BWOM & 0.06 & 0.00 & 1.00 & 0.00 & 0.25 & 3.54 & 13.52 \\
\hline DUAL & 0.01 & 0.00 & 1.00 & 0.00 & 0.12 & 8.07 & 66.18 \\
\hline IBDO & 0.68 & 0.80 & 1.00 & 0.20 & 0.19 & -0.50 & 2.83 \\
\hline MON & 63.29 & 68.87 & 100.00 & 0.00 & 25.26 & -0.93 & 3.09 \\
\hline REMSTER & 890.03 & 0.00 & 102765.00 & 0.00 & 3806.75 & 23.59 & 628.79 \\
\hline SIZE & 13.73 & 13.4 & 18.9 & 10.1 & 1.67 & 0.76 & 3.4 \\
\hline DEBT & 0.67 & 0.64 & 3.06 & 0.06 & 0.33 & 2.44 & 14.81 \\
\hline TENUE & 0.49 & 0 & 1 & 0 & 0.5 & 0.03 & 1.0 \\
\hline ROA & 0.1 & 0.08 & 0.63 & -0.7 & 0.16 & -0.2 & 7.0 \\
\hline
\end{tabular}

Test of linearity: Nonlinearity among the independent variables is one of the classic assumptions which should be regulated. Linearity is a condition that shows an independent 
variable is a linear function of other independent variables. Suppose a high regression equation is linear. In that case, this means that there is a high correlation among the independent variables and regarding the high value of the coefficient of determination, the model has no high reliability. VIF test is used for linearity. Since the obtained VIF value is less than 10, so there is no linearity among the independent variables.

Test of variance heterogeneity: One of the other classic assumptions is the variance heterogeneity. This test for all models shows that all residuals are heterogeneous.

Tests of model selection: In this paper, bilateral F-Limer, bilateral Breusch-Pagan, and Hausman tests are used for selecting the type of model, the results of which are displayed in Table 2.

Table 2

The results of statistical tests

\begin{tabular}{|c|c|c|c|c|c|c|c|c|c|c|c|}
\hline \multirow{2}{*}{ Description } & \multicolumn{2}{|c|}{$\begin{array}{c}\text { F-Limer test } \\
\text { (Section) }\end{array}$} & \multicolumn{2}{|c|}{$\begin{array}{c}\text { F-Limer test } \\
\text { (Section and time) }\end{array}$} & \multicolumn{2}{|c|}{$\begin{array}{c}\text { Breusch-Pagan } \\
\text { test } \\
\text { (Section) }\end{array}$} & \multicolumn{2}{|c|}{$\begin{array}{c}\text { Breusch-Pagan } \\
\text { test } \\
\text { (Section and time) }\end{array}$} & \multicolumn{2}{|c|}{ Hausman test } & \multirow{2}{*}{ result } \\
\hline & statistic & $\begin{array}{l}\text { Probabi- } \\
\text { lity level }\end{array}$ & statistic & $\begin{array}{l}\text { Probabili- } \\
\text { ty level }\end{array}$ & statistic & $\begin{array}{l}\text { Probabili- } \\
\text { ty level }\end{array}$ & statistic & $\begin{array}{l}\text { Probabili- } \\
\text { ty level }\end{array}$ & statistic & $\begin{array}{l}\text { Probabi- } \\
\text { lity level }\end{array}$ & \\
\hline Model 1 & 24.6 & 0.00 & 42.3 & 0.00 & 756 & 0.00 & 754 & 0.00 & 23 & 0.00 & PFSTE $^{1}$ \\
\hline Model 2 & 15.9 & 0.00 & 15.3 & 0.00 & 49 & 0.00 & 39 & 0.00 & 44.3 & 0.00 & PFSTE \\
\hline Model 3 & 17.3 & 0.00 & 17.9 & 0.00 & 451 & 0.00 & 450 & 0.00 & 35.6 & 0.00 & PFSTE \\
\hline
\end{tabular}

The results of the model determination in model one are composed of 5 different tests. The F-Limer test (section), which tests the null hypothesis of the pooled model against the alternative hypothesis, and a panel with fixed sectional effects. Given the statistic and the related level of probability, the null hypothesis is rejected. The F-Limer test (section and time) analyzes the null hypothesis of the pooled model against the alternative hypothesis that is a panel with fixed sectional and temporal effects. Given the statistic and the related level of probability, the null hypothesis is rejected. Breusch-Pagan (section) test evaluates the null hypothesis that is the pooled model against the alternative hypothesis and a panel with random effects. Given the statistic and the related level of probability, the null hypothesis is rejected. The Hausman test examines the null hypothesis that is a panel with random effects against the alternative hypothesis and a panel with fixed effects and given the statistic and the level of probability the null hypothesis is rejected and model with fixed temporal and sectional effects is accepted.

${ }^{1}$ Panel with fixed sectional and temporal effects 
The results of hypothesis testing

The results of the estimation are as follows:

The results of the regression model fitting are depicted in table 3

Table 3

The results of the regression model fitting

\begin{tabular}{|c|c|c|c|c|c|c|c|}
\hline \multirow[b]{2}{*}{ Variable } & \multirow{2}{*}{$\begin{array}{c}\text { Expected } \\
\text { sign }\end{array}$} & \multicolumn{2}{|c|}{ Cost1 Model } & \multicolumn{2}{|c|}{ Cost2 Model } & \multicolumn{2}{|c|}{ Cost3 Model } \\
\hline & & Coefficient & t-Statistic & Coefficient & t-Statistic & Coefficient & t-Statistic \\
\hline $\mathrm{BE}$ & - & 0.106 & $-2.167 * *$ & 0.001 & $1.712^{*}$ & 0.615 & $-3.53 * * *$ \\
\hline BSP & - & 0.920 & $-2.802 * * *$ & 0.752 & 0.803 & 0.426 & -1.962 \\
\hline BWOM & - & 0.141 & $2.792 * * *$ & 0.173 & 0.116 & 0.244 & 0.630 \\
\hline DUAL & + & 0.101 & 0.9142 & 0.033 & 1.098 & 0.114 & -1.615 \\
\hline IBDO & - & 0.237 & $-5.917 * * *$ & 0.022 & $1.941 * *$ & 0.864 & $-2.925^{* *}$ \\
\hline MON & - & 0.530 & 0.8059 & 0.000 & $2.970 * * *$ & 0.000 & 0.860 \\
\hline $\begin{array}{l}\text { R E M - } \\
\text { STER }\end{array}$ & - & 0.004 & $0.005 * * *$ & 0.001 & $-6.964 * * *$ & 0.000 & $1.858^{*}$ \\
\hline SIZE & & 0.174 & $3.729 * * *$ & 0.043 & $2.642 * * *$ & 0.050 & $1.704 *$ \\
\hline TENUE & & 0.721 & 0.6491 & 0.539 & -1.234 & 0.198 & 0.250 \\
\hline DBET & & 0.541 & $-2.755^{* * *}$ & 0.066 & 0.819 & 0.456 & $2.785^{* * *}$ \\
\hline ROA & & 0.131 & 0.5667 & 0.010 & $1.651^{*}$ & 0.026 & $1.877^{*}$ \\
\hline year & & -0.025 & $-11.81 * * *$ & -0.013 & $-6.279 * * *$ & 0.012 & $2.122 * *$ \\
\hline $\mathrm{C}$ & & 1.353 & $17.65 * * *$ & 0.277 & $17.98 * * *$ & 0.151 & $2.764 * * *$ \\
\hline \multicolumn{2}{|c|}{$\mathrm{R}^{2}$} & \multicolumn{2}{|c|}{0.85} & \multicolumn{2}{|c|}{0.80} & \multicolumn{2}{|c|}{0.82} \\
\hline \multicolumn{2}{|c|}{ Adjusted- $\mathrm{R}^{2}$} & \multicolumn{2}{|c|}{0.83} & \multicolumn{2}{|c|}{0.77} & \multicolumn{2}{|c|}{0.79} \\
\hline \multicolumn{2}{|c|}{ DW } & \multicolumn{2}{|c|}{1.59} & \multicolumn{2}{|c|}{1.54} & \multicolumn{2}{|c|}{1.53} \\
\hline \multicolumn{2}{|c|}{ F-statistic } & \multicolumn{2}{|c|}{32.21} & \multicolumn{2}{|c|}{23.23} & \multicolumn{2}{|c|}{25.95} \\
\hline \multicolumn{2}{|c|}{ Prob. } & \multicolumn{2}{|c|}{0.00} & \multicolumn{2}{|c|}{0.00} & \multicolumn{2}{|c|}{0.00} \\
\hline
\end{tabular}

Note: In above Table the $*, * *, * * *$ are significant at the $0.10,0.05$, and 0.01 levels, respectively

Given the respective values of $0.85,0.80$, and 0.82 of the three models obtained from the $\mathrm{R}^{2}$, it is concluded that the changes of the independent variables explain the changes of the only dependent variable of the study in each model. Also, since the value of the statistic related to the detection of autocorrelation (Durbin-Watson) in all three models is between 1.8 and 2.05, 
therefore no autocorrelation problem exists between variables. Since the statistic and level of significance of F-Fisher is smaller than 5\%, the entire model is significant, statistically.

The results of model fitting which are reported in Table 3 indicate that the variable (BE) the proxy of board effort, which is measured by the number of annual sessions as predicted has a negative and significant relationship with the agency costs in the first and third cost models. It supports the idea that more numbers of board members will result in lower agency cost for companies. Such results are in line with findings of the Kurand Copper (2013), Arosa et al. (2010), and Illaboya and Obaretin (2015). In contrast, the second cost model demonstrates a positive association.

The presented results in Table 3 also suggest a negative and significant association between board expertise (BSP) and agency costs in the only first cost model. It means that an educated board with members having $\mathrm{PhD}$ degree could mitigate the agency costs through an optimized level. In other words, a board with highly- educated members carries fewer costs for the firms. It is notable that since only one model shows the association, therefore our results are not robust in this regard. These findings are consistent with our expectations, and also in line with the studies of Van Ness et al. (2010), Von and Phan (2013), and Illaboya and Obaretin (2015).

CEO duality means appointing one of the board director's member as chief executive officer of the company. The results of this association report, in contrast to our expectation, no significant association in all three models. The studies of Sajid et al. (2012) and Arosa et al. (2013) find a positive and significant association in this regard.

Based on reported analyses in Table 3, the independency of board director's (IBDO) members has a negative impact on the agency costs, in the first and third models, which is another tested variable in this study. These findings are consistent with our expectation, demonstrating the increase in the proportion of independent managers' number leads to a decrease in agency costs. In contrast, the results of the second model suggest that the board of director independence is positively associated with agency cost. Consequently, our findings of this hypothesis are not robust. It is notable that previous literature also reports an ambiguous relationship, Salehi, Tarighi \& Safdari (2018) find no association, and Wyatti (1990), similar to our findings, suggest a negative/positive relationship. Ahmed and Sanda (2008) suggest a positive association.

In line with the studies of Sajid et al. (2012), Rashid (2016), and Balasingham et al. (2017), the effect of managerial ownership is also evaluated in this paper, and some results are obtained based on the predictions. The relationship between managerial ownership and agency costs is positive and significant in the only second model, while the first and third models show no significant relationship in this context. The results of model 2 indicate that higher shares 
owned by the board of director's members cause more agency cost for companies. Taken together, it is noted that our findings are not robust about this association.

The other variable test in this paper is the compensation of the board's members. The results of all three models indicate a significant association of these variables; in contrast to our expectations and based on the theoretical principles, the relationship between compensation and the agency costs is positive in the first and third models. The findings suggest that higher compensation is recognized as a cost element for companies. In other words, the positivity and significance of this relation show that providing compensation is not economically and statistically justifiable for companies. Further analyses of second cost model suggest that, in line with the results of Florackis (2008) and Sajid et al. (2012), offering compensation for board's members will result in lower agency cost due to a negative association of the second model.

Based on the results of the control variable, the firm size in all three models has a positive and significant relationship with the agency costs. It means that bigger companies experience higher cost. Moreover, the results of fitting show that CEO tenure, in all three models, has no significant relationship with the agency costs. The results also evidence that an ambiguous (respectively negative, neutral and positive effect for three models) relationship between financial leverage and the agency costs. Finally, it is suggested that the higher return of asset (ROA) is incorporated with higher agency cost.

\section{Conclusion}

The main objective of the current study is investigating the effect of the board of directors' characteristics on the level of agency cost in Tehran stock exchange. In these days' complicated markets and the modern world, it is difficult to manage companies, and even small firms, by the owner of wealth; this issue provides a mechanism, which separates wealth owners and managers. On the other hand, the conflict between these two parties has always been the topic of academic debates. Therefore, establishing a permanent and fair relation between them, to minimize the moral risk plies a significant role in the capital market. Consequently, the presence of such conflicts obliged the shareholders to bear some expenses, which are called the agency costs. The exploration of effective factors on the value of this cost may provide further guidance to improve the business environment.

According to the issue mentioned above, firstly, we show that the greater number of board directors' meeting may improve the level of agency costs (based on two cost models), and it also may increase the level of agency costs (based on one model). Meaning, following our expectation greater number of board's sessions as well as increase education gives a deeper perception to the members, which in turn helps them to provide more practical and helpful 
advice for managers as well as the establishment of efficient monitoring policies. Moreover, we evidence that the presence of women in the board of directors, and the ownership of firms' share by the members of the board director may increase the level of agency cost for firms. One possible explanation for such findings is a lack of experienced and knowledgeable women on the board. In this regard, Moez et al. (2018) argue that the positive effect of women members on the board of directors is attributed to their education, business education and nationality. Since only one (out of three) model suggest these associations, our findings are less severe in these regards. Further analyses document that appointing one of the board director's members as chief executive officer (CEO duality) plays no significant role in mitigating the agency cost. The similar findings, based on our three cost models, suggest a robust conclusion in this context. Such findings mean that other controlling policies do not let dual managers show opportunistic behavior, leading intense agency problems. Furthermore, two agency cost models demonstrate that the increase in the proportion of independent managers' number leads to a decrease in agency costs. In contrast, one another model suggests a reverse association. It means that independent managers, who have no financial interest in firms, have fewer concerns for its performance, resulting in greater agency costs. .We finally find that the compensation of the board's director is positively (in two agency cost models) and negatively (in one agency cost model) associated with agency costs. Meaning, greater compensation bears greater cost on the firms, which in turn increases agency costs. Similar to prior literature, our findings imply an ambiguous conclusion in these contexts.

\section{References}

Abdul Gafoor, C.P., Mariappan, V., \& Thyagarajan, S. (2018). Board characteristics and bank performance in India. IIMB Management Review, 30 (2), 160-167.

Abdullah, S. and Ismail, K. (2016), "Women directors, family ownership and earnings management in Malaysia". Asian Review of Accounting, 24 (4) 525-550.

Agung Dharmawan Buchdadi, I Gusti Ketut Agung Ulupui, Sholatia Dalimunthe, Bagas Gusti Pamungkas, and Yaumil Fauziyyah. (2019). Board of Director Meeting and Firm Performance. Research Article, 23(2).

Ang, J. Cole, R. Lin, J. (2000). “Agency Costs and Ownership Structure.” The Journal of Finance, 55 (1) 81-106. Anthony, k.Biekpe, N. (2008). "The relationship between size, board composition, CEO duality and firm performance: experience from china". Corporate Ownership \& Control. 4(2) 114-122.

Antoni , D. Corti, R. Sohn. H. Y, Eerdmans. P, Gerrit. A (2011).“Long-term clinical outcomes of biodegradable polymer biolimus-eluting stents versus durable polymer sirolimus-eluting stents in patients with coronary artery disease (LEADERS): 4 year follow-up of a randomised non-inferiority trial". Science direct, 378(9) 19301948.

Arosa, B, Iturralde, T, Maseda, A. (2013)." The board structure and firm performance in SMEs: Evidence from Spain". Investigaciones Europeas de Direccion, 19(3)127-135.

Aslan, H, Kumar, P. (2014)." National Governance Bundles and Corporate Agency Costs: A Cross-Country Analysis". Corporate Governance: An International Review, 22(3)230-251. 
Balasingham, B. Sutharson, K. Chandrasekhar, K. Michael, T. Eswaran, V. (2017). "The issuance of warrants in rights offerings: Agency costs and signaling effects". Australian Journal of Management, 42(1)1-29.

Berezinets, I., Garanina, T. and Ilina, Y. (2016), "Intellectual capital of a board of directors and its elements: introduction to the concepts”. Journal of Intellectual Capital, 17 (4)632-653.

Buchwald, A.(2016)."Competition, outside directors and executive turnover: Implications for corporate governance in the EU". Managerial and Decision Economics, 37(4-5)213-371.

Cabeza-García, L., Fernández-Gago, R., and Nieto, M. ( 2018) Do Board Gender Diversity and Director Typology Impact CSR Reporting? European Management Review, 15: 559- 575. https://doi.org/10.1111/emre.12143.

Cadot, J. (2013)." Agency costs, vertical integration and ownership structure: the case of wine business in France". Journal of agricultural and applied economics, 40(3)28-88.

Chernenko, S, C, Foley, F, Greenwood, R. (2012).” Agency Costs, Mispricing, and Ownership Structure”. Financial Management, 41(4)1-30.

Cui, H. Mak, Y, T. (2002)." the Relationship between Managerial Ownership and Firm Performance in High R\&D Firms", Journal of corporate finance, 8(1)313-336.

Dey, A. (2008). "Corporate Governance and Agency Conflicts". Journal of Accounting Research, 46(5)11431181.

Elmagrhi, MH, Ntim, CG, Elamer, AA, Zhang, Q. (2019). A study of environmental policies and regulations, governance structures, and environmental performance: The role of female directors. Business Strategy and Environment, 28(1)206-220.

Eluyela, D.F., Akintimehin, O.O., Okere, W., Ozordi, E., Osuma, G.O., Ilogho, S.O., \& Oladipo, O.A. (2018). Board meeting frequency and firm performance: Examining the nexus in Nigerian deposit money banks. Heliyon, 4(10).

Ely, K. (1991)." Interindustry differences in the relation between compensation and firm performance". Journal of accounting research, 29(1)37-58.

Fatma, B.M. (2010).Interactions between Free Cash Flow, Debt Policy and Structure of Governance: Three Stage Least Square Simultaneous Model Approach". Journal of Management Research, 3(2)1-34.

Fidanoski, F, Mateska, V, Simeonovski, K. (2014).” Corporate Governance and Bank Performance: Evidence from Macedonia". Economic Analysis, 47(2)76-99.

Fleming, G. Heaney, R. McCosker, R. (2005). “Agency Cost and Ownership Structure in Australia”. Pacific Basin Finance Journal, 1(13)29-52.

Florackis, C. (2008). "Agency costs and corporate governance mechanisms: evidence for UK firms". International Journal of Managerial Finance, 4(1)37-59.

Garanina, T, Kaikova, E. (2016).”Corporate governance mechanisms and agency costs: cross-country analysis”. Corporate Governance: The International Journal of Business in Society, 16(2)347-360.

Gray, S. and Nowland, J. (2018). "Director workloads, attendance and firm performance". Accounting Research Journal, 31(2)214-231.

Gulzar, M.A.; Cherian, J.; Hwang, J.; Jiang, Y.; Sial, M.S. (2019). The Impact of Board Gender Diversity and Foreign Institutional Investors on the Corporate Social Responsibility (CSR) Engagement of Chinese Listed Companies. Sustainability, 11(2)1-19.

Harjoto, M., Laksmana, I. and Yang, Y. (2019), "Board nationality and educational background diversity and corporate social performance". Corporate Governance, 19 (2)217-239.

He, E, Sommer, D, W. (2010). "Separation of Ownership and Control: Implications for Board Composition.” The Journal of Risk and Insurance, 77(2)265-295.

Henry, D. (2010)." Agency Costs, Ownership Structure and Corporate Governance compliance: A private contracting perspective". Pacific-basin finance journal, 18(1)24-46.

Hewa-Wellalage, N, Locke, S. (2011). "Does CEO Duality is Really Matter? Evidence from an Emerging Market". Corporate Ownership and Control, 8(4)112-122. 
Hong, B, Li, ZH, Minor, D. (2015)." Corporate Governance and Executive Compensation for Corporate Social Responsibility". Springer Science+ Business, 136(1)199-213.

Ilaboya, O. J. Obaretin O. (2015).” Board Characteristics and Firm Performance: Evidence from Nigerian Quoted Companies". Academic Journal of Interdisciplinary Studies, 4(1)283-290.

Jensen, M, C. (1986)," Agency Costs of Free Cash Flow, Corporate Finance, and Takeovers". American Economic Review, 76(2)323-329.

Jensen.M, C, Meckling, W, H. (1976).” Theory of the Firm: Managerial Behavior, Agency Costs and Ownership Structure". Journal of Financial Economics, 3(4)305-360.

Jiraporn, P, Chintrakarn, P, Kim, J, CH, Liu, Y. (2012).” Exploring the Agency Cost of Debt: Evidence from the ISS Governance Standards". Journal of financial Services research, 44(2)205-227.

Johl, S, K, Kaur, S, Cooper, B, J. (2013)." Board characteristics and firm performance: evidence from Malaysian public listed firms". Journal of Economics, Business and Management, 3(2)239-243.

Jurkus, A, F, a, Jung Chul Park, J, CH, Woodard, L, S. (2011).” Women in Top Management and Agency Costs “. Journal of Business Research, 4(2)180-186.

Jurkus, A, F, Park, J, CH, Woodard, L, S. (2011), "Women in top management and agency costs". Journal of Business Research, 64(2)180-186.

Kalay, A. (2014).” International Payout Policy, Information Asymmetry, and Agency Costs". Journal of Accounting Research, 52(2)472-457.

Karart1, T. (2014)." Impact of ownership structure on leverage of non-financial firms in developing countries". International Research Journal of York University, 1(1) 16 - 46.

Kilic, M. (2015)." The Effect of Board Diversity on the Performance of Banks: Evidence from Turkey". International Journal of Business and Management, 10(9)182-192.

Li, M. Chnki, E. (2008).”Ownership Structure, Corporate Governance and Agency Cost of Equity”. Journal of financial research, 19(4)125-141.

Maria-Priego, A, Montserrat-ManzanequeLizano, M, M, Merino-Madrid, E. (2014).” The effect of internal corporate governance control measure on firms". Financial distress likelihood, 19(1)111-121.

Mark Bradshaw, Guanmin Liao, Mark (Shuai) Ma, (2019). Agency costs and tax planning when the government is a major Shareholder. Journal of Accounting and Economics, 67( 2-3)255-277.

Mazlina, M. AyoibChe, A. (2009). "Agency Theory and Managerial Ownership: Evidence from Malaysia”, Annual Asian Academic Accounting Association Conference Program, Turkey, November 15.

Merendino, A. (2013)." Corporate Governance: A Critical Comparison among International Theories, Codes of Best Practices, and Empirical Research”. Department of Economics and Management, 3(6)304-315.

Moez Bennouri, Tawhid Chtioui, Haithem Nagati, Mehdi Nekhili. (2018). Female board directorship and firm performance: What really matters? Journal of Banking \& Finance, (88)267-291. https://doi.org/10.1016/j. jbankfin.2017.12.010.

MohdSaad, N. (2010)." Corporate Governance Compliance and the Effects to Capital Structure in Malaysia”. Journal of Economics and Finance, 2(1)105-114.

Muller, E, Spitzoener, A, (2006). "Managerial ownership and company performance in German small and medium-sized private enterprises". German economic review, 7(2)233-247.

Mustapha, M, Ahmad, A, CH. (2011)."Agency theory and managerial ownership: evidence from Malaysia”, Managerial Auditing Journal, 26(5)419-436.

Petchsakulwong, P., \& Jansakul, N. (2018). Board of directors and profitability ratio of Thai non-life insurers. Kasetsart Journal of Social Sciences, 39(1)122-128.

Rashid, A. (2016). "Managerial Ownership and Agency Cost: Evidence from Bangladesh". Journal of Business Ethics, 137(3)609-621.

Rosenstein, S. Wyattj, G (1990)."Outside directors, board indecent and shareholder wealth". Journal of economics, 26(2)175-191. 
Sajid, G, Muhammad, S, Nasir, R, Farman, A. (2012)." Agency cost, corporate governance and ownership structure: the case of Pakistan”. International Journal of Business and Social Science, 3(9)268-277.

Salehi, M., Tahervafaei, M., \& Tarighi, H. (2018). The effect of characteristics of audit committee and board on corporate profitability in Iran. Journal of Economic and Administrative Sciences, 34(1)71-88.

Salehi, M., Tarighi, H., \& Safdari, S. (2018). The relation between corporate governance mechanisms, executive compensation and audit fees: Evidence from Iran. Management Research Review.

Salehi. M., and Marziyeh Farzaneh (2018). The impact of board's human capital on the relationship between board's characteristics and firm's performance in Iran. International Journal of Learning and Intellectual Capital, 15(4)293-308.

Saltaji, I, M. (2013)."Corporate Governance and Agency theory how to control agency costs". Internal auditing \&risk management, 4(32)47-60.

Schmidt, I. M. (2019). Board Gender Diversity and Firm performance: How do Educational Levels and Board Gender Quotas affect this relationship? Evidence from Europe (Dissertation). Retrieved from http://urn.kb.se/ resolve?urn=urn:nbn:se:uu:diva-377175.

Singh, M, Davidson, W, N. (2003)." Agency costs, ownership structure and corporate governance mechanisms". Journal of Banking \& Finance, 27(5)793-816.

Stagliano, R, Rocca, M, L, Rocca, T, L. (2014).” Agency costs of free cash flow, internal capital markets and unrelated diversification". Review of Managerial Science, 8(2)145-174.

Teixeira, M. (2012)." Agency Costs, Firm Value, and Corporate Investment". PhD thesis in management, the Erasmus, school of Economics, the Erasmus University Rotterdam, Rotterdam, Holland.

Van Ness, R, K, Miesing, P, Kang, J. (2010). "Board of director composition and financial performance in a Sarbanes-Oxley". Academy of Business and Economics Journal, 10(5)56-74.

Villaloga, B, Amit, R. (2006)."How do Family ownership, control and management affect firm value". Journal of Financial Economics, 80(2)385-417.

Vo, D, Phan, TH. (2013)." Corporate Governance and Firm Performance: Empirical Evidence from Vietnam". Economic Regulation Authority, 6(6)1-13.

Wangfing, Z, Lihong, C. (2015).”Family involvement, internal control and agency costs-evidence from china's listed family firms". Perspectives in Science, 7(1)45-51.

Wellalage, N, H, Locke, S. (2011)." Women on board, firm financial performance and agency costs". Asian Journal of Business Ethics, 2(2)113-127.

Yeo, H. (2012)." Impacts of the board of directors and ownership structure on consolidation strategies in shipping industry". The Asian Journal of Shipping and logistics, 28(1)19-40. 